\title{
Determination of the Decision Support System Based on Teacher Performance Rewards Receiver With AHP method on SMK Negeri 1 Beringin
}

\author{
Subowo $^{1}$, Fristi Riandari ${ }^{2}$ \\ 1.2 Engineering Informatics Program, STMIK Pelita Nusantara Medan, Jl. Iskandar Muda 1 \\ Medan, North Sumatra 20154, Indonesia \\ E-mail: subowo19997@gmail.com
}

\begin{abstract}
Teacher performance evaluation of SMK Negeri 1 Beringin Deli Serdang Regency was conducted on three samples of teachers as teacher performance appraisal of data as material for consideration of the continued relationship of cooperation for the future budget. Components of performance appraisal of teacher performance at VOCATIONAL SCHOOL 1 Beringin Deli Serdang Regency are work performance, performance quantity, performance discipline, cooperation, and loyalty. Problems with the teacher performance appraisal process that occur due to unclear criteria and assessment weights. A method in a decision support system can help the optimal decision making process, the AHP method in Determining the performance evaluation of honorary employees. There are three employee performance weights, the which are very good, good, sufficient and good enough,
\end{abstract}

Keywords: Decision Support System (DSS), Analytical Hierarchy Process (AHP), recipient Rewards (Bonus) based on teacher performance

\section{Introduction}

The rapid development of information technology not only on technology hardware and software alone, but also developed a computational method and one method of computing that is developing today is the method of decision-making system (Decision Support Systems). Decision Support System (DSS) is used as a tool for decision makers to expand the capabilities of the decision makers, but not to replace the judgment of the decision makers (Irmala, Kom, Iswadi, Kom, and Hadi Suprayetno, ST: 2019),

SMK Negeri 1 Beringin is a school that has a characteristic that is never eliminated ie become a pilot school and school Adwiyata that has been recognized throughout Indonesia and, SMK 1 Beringin is a Public Schools that without the fence, which is led by the school principal ILYAS, M. Pd as the principal of SMK Negeri 1 Beringin. This school has a $3 \mathrm{~K}$ are: Discipline, Hospitality, and neatness.

\section{Theory}

\subsection{AHP procedure}

Basically, the procedure or steps in the method of AHP include:

a. Define the problem and determine the desired solution, and then draw up a hierarchy of problems faced.

b. Determining the priority elements, the first step in determining the priority is to make a comparison a couple of elements, comparing elements in pairs according to the criteria given. Pairwise comparison matrix filled mengggunakan numbers to represent the relative importance of one element against another element.

c. SintesisPertimbangan-consideration of pairwise comparisons were synthesized to obtain overall priorities. Things that are done in this step are: Summing up the values of each column of the matrix, dividing each value of the column with the total column in question to obtain a normalization matrix, and summing the values of each row and dividing by the number of elements to get average value.

d. Measuring Consistency In making the decision, it is important to know how well the consistency that exists because we do not want decisions based on consideration with a low consistency. Things that do in this step is: Multiply each value pasa first column with the relative priority of the first element, the value in the second column with the relative priority of the second element, and so on, the sum of each row, the result of the sum of the line divided by the element relative priorities concerned and sum the results for the above with the number of existing elements, the result is called the max. $\lambda$

Calculate Consistency Index (CI)

by the formula: 
$\mathrm{CI}=(\max -\mathrm{n}) / \mathrm{n}$

where $\mathrm{n}=$ number of elements.

Calculate the ratio Consistency / Consistency Ratio (CR)

by the formula:

$\mathrm{CR}=\mathrm{CI} / \mathrm{RC}$

Where $\quad \mathrm{CR}=$ Consistency Ratio

$\mathrm{CI}=$ Consistency Index

$\mathrm{IR}=$ Random Consistency Index

Hierarki.Jika consistency check value is more than $10 \%$, then the judgment must be corrected data assessment. However, if the consistency ratio (CI / RI) is less than or equal to 0.1 , then the results could be declared true peritungan.

List of Random Consistency Index (IR) can be seen in table 2.2

Table 1

List of Random Consistency Index

\begin{tabular}{cc}
\hline Matrix size & value IR \\
\hline 1.2 & 0,00 \\
3 & 0.58 \\
4 & 0.90 \\
5 & 1.12 \\
6 & 1.24 \\
7 & 1.32 \\
8 & 1.41 \\
9 & 1.45 \\
10 & 1.49 \\
11 & 1.51 \\
12 & 1.48 \\
13 & 1.56 \\
14 & 1.57 \\
15 & 1.59 \\
\hline
\end{tabular}

Source: Kusrini, Concepts and Applications of Decision Support Systems (2007)

1. Irmala, S.Kom

a) Make a comparison matrix of criteria

Table 2.

Pairwise Comparison Matrix

\begin{tabular}{lcccc}
\hline & Discipline & Pres. Work & Loyalty & behavior \\
\hline Discipline & 3 & 2 & 3 & 2 \\
Pres. Work & 1.5 & 3 & 2 & 3 \\
Loyalty & 1 & 1.5 & 3 & 2 \\
behavior & 1.5 & 1 & 1.5 & 3 \\
amount & 7 & 7.5 & 9.5 & 10 \\
\hline
\end{tabular}

Number 3 on the column line discipline discipline describe the same level of importance among the same interests between discipline by discipline, while the number 2 in column performance discipline row shows performance slightly less important than the discipline. Figures 1.5 column line discipline work performance is the result of the calculation 3 / value on the column line job performance discipline (2). Other figures obtained in the same manner.

b) Create a matrix of criteria values

Table 3.

Matrix Values Criteria

\begin{tabular}{lcccccc}
\hline & Discipline & $\begin{array}{c}\text { Pres. } \\
\text { Work }\end{array}$ & Loyalty & behavior & amount & $\begin{array}{c}\text { Priority } \\
\text { weights }\end{array}$ \\
\hline Discipline & $0: 43$ & $0: 26$ & $0: 31$ & 0.2 & 1.2 & 0.3 \\
Pres. Work & $0: 21$ & 0.4 & $0: 21$ & 0.3 & $1: 12$ & $0: 28$ \\
Loyalty & $0: 14$ & 0.2 & $0: 31$ & 0.2 & 0.85 & $0: 21$ \\
behavior & $0: 21$ & $0: 13$ & $0: 11$ & 0.3 & 0.75 & $0: 19$ \\
\hline
\end{tabular}

Matrix This criterion values obtained by dividing each element corresponds to the total column as follows: for $\mathrm{C} 1$

$3 / 7=0: 43$

$1.5 / 7=0.21$

$1 / 7=0: 14$ 
$1.5 / 7=0.21$

To find the value of the column number by adding individual elements on each column of the row as follows:

$0.43+0.26+0.31+0.2=1.2$

And to get the value of the priority weight by dividing the value of the column number with the number of elements are as follows:

$1.2 / 4=0.3$

For grades four taken from the number of elements.

c) Creating consistency index $(\mathrm{Cl}) \lambda$ maks $\mathrm{n} / \mathrm{n}-1$

$\lambda$ maks $=$ number of elements in the matrix $Y$

$\mathrm{N}$

$\lambda$ maks $=(7 * 0.3)+(7.5 * 0.28)+(9.5 * 0.21)+(10 * 0.9)=8.1$

$\mathrm{CI}=8.1-4 / 4-1=1,025$

$\mathrm{RI}$ is taken from a random value generator.

Table 4.

Random Index Values

\begin{tabular}{|c|c|c|c|c|c|c|c|c|c|}
\hline $\begin{array}{c}\text { The size of the } \\
\text { matrix }\end{array}$ & 1.2 & 3 & 4 & 5 & 6 & 7 & 8 & 9 & 10 \\
\hline random Index & 0.0 & 0.58 & 0.9 & 1.12 & 1.24 & 1.32 & 1.42 & 1.45 & 1.49 \\
\hline
\end{tabular}

Because the matrix berordo 4 then the value of $\mathrm{RI}=0.9$

Then $\mathrm{CR}=1,025 / 0.9=1,139$

\section{Conclusion}

After a discussion of the previous chapters, the author can draw conclusions as follows:

a. In determining the recipient Teacher rewards (bonus) at SMK Negeri 1 Beringin can be applied to the criteria of discipline, work performance, loyalty and behavior because of these criteria can be used as a determination of the performance of teachers.

b. By applying the AHP method can be applied very well and in pengimplementasinya, AHP was able to show that one of the alternatives is a priority of the decision.

c. In designing a decision support system for the determination of the receiving rewards (bonus) based on the performance of teachers at SMK 1 Beringin very good at programming language Visual Basic 2008 and this application can be applied in the determination of the receiving rewards (bonus) Master.

\section{Reference}

[1] Pakpahan, A. et al. (2019) 'Implementation of Certainty Factor Method for Damage Diagnoses of Photocopy Machine Implementation of Certainty Factor Method for Diagnoses of Photocopy Machine Damage', Journal of Physics: Conference Series, 1255 (012 059). doi: 10.1088 / 1742-6596 / 1255/1/012059.

[2] Sembiring, AS et al. (2019) 'Implementation of Certainty Factor Method for Expert System', Journal of Physics: Conference Series PAPER, 1255 (012 065). doi: 10.1088 / 1742-6596 / 1255/1/012065.

[3] Sihotang, HT et al. (2019) 'Expert System for Chicken Disease Diagnosis using Bayes Theorem', Journal of Physics: Conference Series PAPER, 1230 (012 066). doi: 10.1088 / 1742-6596 / 1230/1/012066.

[4] Fitrian RM et al., "Digital Dictionary Using Binary Search Algorithm," J. Phys. Conf. Ser., Vol. 1255, no. 012 058, 2019.

[5] S. Panjaitan, M. Amin, S. Lindawati, R. Watrianthos, and HT Sihotang, "Implementation of Apriori Algorithm for Analysis of Consumer Purchase Patterns Implementation of Apriori Algorithm for Analysis of Consumer Purchase Patterns," J. Phys. Conf. Ser. Pap., Vol. 1255, no. 012 057, 2019. 